\title{
Gebruikersonderzoek ROA-rapport 'de arbeidsmarkt naar opleiding en beroep'
}

Citation for published version (APA):

Nieuwland, R. K. M., \& de Grip, A. (1993). Gebruikersonderzoek ROA-rapport 'de arbeidsmarkt naar opleiding en beroep'. Researchcentrum voor Onderwijs en Arbeidsmarkt, Faculteit der Economische Wetenschappen. ROA Working Papers No. 2 https://doi.org/10.26481/umarow.1993002

Document status and date:

Published: 01/01/1993

DOI:

10.26481/umarow.1993002

Document Version:

Publisher's PDF, also known as Version of record

\section{Please check the document version of this publication:}

- A submitted manuscript is the version of the article upon submission and before peer-review. There can be important differences between the submitted version and the official published version of record.

People interested in the research are advised to contact the author for the final version of the publication, or visit the DOI to the publisher's website.

- The final author version and the galley proof are versions of the publication after peer review.

- The final published version features the final layout of the paper including the volume, issue and page numbers.

Link to publication

\footnotetext{
General rights rights.

- You may freely distribute the URL identifying the publication in the public portal. please follow below link for the End User Agreement:

www.umlib.nl/taverne-license

Take down policy

If you believe that this document breaches copyright please contact us at:

repository@maastrichtuniversity.nl

providing details and we will investigate your claim.
}

Copyright and moral rights for the publications made accessible in the public portal are retained by the authors and/or other copyright owners and it is a condition of accessing publications that users recognise and abide by the legal requirements associated with these

- Users may download and print one copy of any publication from the public portal for the purpose of private study or research.

- You may not further distribute the material or use it for any profit-making activity or commercial gain

If the publication is distributed under the terms of Article $25 \mathrm{fa}$ of the Dutch Copyright Act, indicated by the "Taverne" license above, 


\section{GEBRUIKERSONDERZOEK ROA-RAPPORT 'DE ARBEIDSMARKT NAAR OPLEIDING EN BEROEP'}

ROA-W-1993/2

R.K.M. Nieuwland, A. de Grip

RESEARCHCENTRUM VOOR ONDERWIJS EN ARBEIDSMARKT

Faculteit der Economische Wetenschappen

Rijksuniversiteit Limburg

Maastricht, juni 1993 
CIP-GEGEVENS KONINKLIJKE BIBLIOTHEEK, DEN HAAG

Nieuwland, R.K.M.

Gebruikersonderzoek ROA-rapport 'De arbeidsmarkt naar opleiding en beroep' / R.K.M. Nieuwland, A. de Grip. - Maastricht: Researchcentrum voor Onderwijs en Arbeidsmarkt. - (ROAW-1993/2)

ISBN 90-5321-105-5 in spiraalband

Trefw.: arbeidsmarkt; Nederland/onderwijs en arbeidsmarkt; Nederland 


\section{INHOUDSOPGAVE}

Bladzijde

VOORWOORD

i

$\begin{array}{ll}\text { 1. INLEIDING } & 1\end{array}$

2. OPZET DATAVERZAMELING 3

3. RESULTATEN GEBRUIKERSONDERZOEK 5

$\begin{array}{lr}\text { 4. BESLUIT } & 18\end{array}$

BIJLAGE 1. VRAGENLIJST ARBEIDSVOORZIENINGSINSTELLINGEN 20

BIJLAGE 2. SPECIFIEKE ANTWOORDMOGELIJKHEDEN VAN 27 ANDERE DOELGROEPEN 


\section{VOORWOORD}

In dit onderzoek wordt verslag gedaan van een enquête-onderzoek onder de afnemers van het tweejaarlijkse ROA-rapport 'De arbeidsmarkt naar opleiding en beroep'. Het onderzoek is onder supervisie van dr. A. de Grip uitgevoerd door R. Nieuwland, in het kader van zijn doctoraalstage. Met dank aan prof. dr. J. Kasper (Rijksuniversiteit Limburg), H. Roukens (RBA Noord-Holland Noord), drs. Th. Wagemans (DSM), drs. G. de Wit (LDC), dr. G. Wolfs (Provincie Limburg) en prof. dr. J. Heijke en drs. E. Willems (ROA) voor hun commentaar op de onderzoeksopzet en/of concept-vragenlijst. 


\section{INLEIDING}

Het onderzoek van het Researchcentrum voor Onderwijs en Arbeidsmarkt (ROA) richt zich voor een belangrijk deel op de aansluitingsproblematiek tussen onderwijs en arbeidsmarkt. Een centrale rol wordt daarbij ingenomen door de onderzoeksopdracht gericht op de instandhouding en de verdere ontwikkeling van een informatiesysteem onderwijs-arbeidsmarkt. Dit onderzoek dat wordt uitgevoerd in opdracht van het Ministerie van Onderwijs en Wetenschappen, het Centraal Bestuur voor de Arbeidsvoorziening en het Landelijk Dienstverlenend Centrum voor studie- en beroepskeuzevoorlichting (LDC) heeft als doel arbeidsmarktinformatie te genereren die bruikbaar is voor verschillende beleidsterreinen binnen het onderwijs- en/of arbeidsmarktbeleid. Centraal daarbij staat het gebruik van de informatie bij het studie- en beroepskeuzevoorlichtingsbeleid. In het kader van dit onderzoeksproject draagt het ROA zorg voor de volgende informatieprodukten:

- Het tweejaarlijkse rapport De arbeidsmarkt naar opleiding en beroep ten behoeve van de verschillende beleidsterreinen, met actuele gegevens, trends en middellange-termijn prognoses van vraag en aanbod op de arbeidsmarkt.

- Het jaarlijks vernieuwen van de actuele arbeidsmarktinformatie voor de statistische bijlage van het rapport De arbeidsmarkt naar opleiding en beroep.

- Het jaarlijks aanleveren van de arbeidsmarktindicatoren en -prognoses aan het LDC, die deze informatie gebruikt voor verschillende voorlichtingsprodukten, waaronder tot op heden het geautomatiseerde informatiesysteem voor studie- en beroepskeuzevoorlichting I-See! een prominente plaats inneemt.

De afgelopen jaren is zowel van de zijde van de opdrachtgevers als van andere afnemers van ROA-publikaties met betrekking tot het informatiesysteem onderwijs-arbeidsmarkt feedback geleverd op de inhoud van het informatiesysteem en de vorm waarin de informatie wordt gepresenteerd. Om op deze punten een meer systematisch beeld te krijgen van de mate waarin de ROA-informatie tegemoet komt aan de gebruikerswensen, is eind 1992/begin 1993 een enquête-onderzoek opgezet naar de gebruikswaarde van het ROA-rapport 'De arbeidsmarkt naar opleiding en beroep tot $1994^{\prime \prime}$.

De centrale aandachtspunten van dit gebruikersonderzoek vormen de volgende onderzoeksvragen:

- Welke organisaties hebben het rapport en de statistische bijlage afgenomen en hoe weet men af van het bestaan ervan?

- Voor welke doeleinden gebruikt men het rapport en de statistische bijlage?

- Welke waardering geeft men het rapport en de bijbehorende statistische bijlage?

- Is het aggregatieniveau waarop de gegevens in het rapport en de statistische bijlage worden gepresenteerd adequaat?

1. De evaluatie van de gebruikswaarde van de ROA-informatie voor de afnemers van de LDC-produkten valt derhalve buiten dit onderzoek. 
$-2-$

- In hoeverre wordt het wenselijk geacht om bepaalde arbeidsmarktinformatie uit te breiden?

- Bestaat er belangstelling voor arbeidsmarktinformatie op diskette?

Deze hoofdvragen van het onderzoek zijn geoperationaliseerd in diverse meer specifieke vragen, waar verderop nader op zal worden ingegaan. De verdere opbouw van dit enquêteverslag is als volgt. Eerst zal in hoofdstuk 2 van het werkdocument kort worden ingegaan op de opzet van het enquête-onderzoek. Daarna wordt in hoofdstuk 3 verslag gedaan van de enquête-uitkomsten. Tenslotte worden in hoofdstuk 4 de belangrijkste conclusies van het gebruikersonderzoek kort samengevat. 


\section{OPZET DATAVERZAMELING}

$\mathrm{Na}$ de formulering van de centrale onderzoeksvragen, werd een begin gemaakt met de dataverzameling. Na overleg met enkele medewerkers van het ROA en de vakgroep marketing van de economische faculteit van de Rijksuniversiteit Limburg, werd een eerste versie van de schriftelijke vragenlijst opgesteld. Deze versie werd verschillende malen getest, waarna een definitieve versie tot stand kwam. De uiteindelijke mailing bestond uit de vragenlijst, gefrankeerde retourenveloppe, begeleidende brief en een korte brief waarin werd vermeld dat de nieuwe geactualiseerde statistische bijlage verkrijgbaar is. De vragenlijst is opgenomen in bijlage $1^{2}$.

Op basis van de samenstelling van het adressenbestand van de afnemers van het rapport beschikbaar was, werd besloten de gebruikers in te delen in vijf doelgroepen: arbeidsvoorzieningsinstellingen, bedrijven, onderwijsinstellingen, overheidsinstellingen en 'overige gebruikers'. De groep 'overig' bestaat onder andere uit verschillende onderzoeksinstituten, stichtingen en particulieren; een verdere onderverdeling van deze doelgroep was niet relevant. Alle doelgroepen kregen dezelfde vragenlijst opgestuurd. De enige uitzondering hierop vormden de antwoordmogelijkheden voor de volgende twee vragen:

2a Voor welke doeleinden heeft $u$ het rapport en de statistische bijlage gebruikt?

$14 \mathrm{~d}$ Voor welke doeleinden wilt $\mathrm{u}$ de diskette gebruiken?

De verschillende antwoordmogelijkheden op deze vragen voor de andere doelgroepen zijn opgenomen in bijlage 2.

Helaas was het niet mogelijk te beschikken over de adressen van alle afnemers van het ROArapport. Voor een belangrijk deel werd dit veroorzaakt door de bestellingen die plaatsvonden via de boekhandel. In eerste instantie, bestond het totale adressenbestand uit 183 bruikbare adressen, verdeeld naar de volgende doelgroepen:

Aantal adressen

Arbeidsvoorzieningsinstellingen

Bedrijven

27

Onderwijsinstellingen

Overheidsinstellingen

37

Overig

39

Vervolgens zijn 100 vragenlijsten meegestuurd met de nieuwe, geactualiseerde statistische bijlage die door het CBA worden verspreid. Het betreft hier met name de eerste doelgroep: de arbeidsvoorzieningsinstellingen. Daarbij wordt de kanttekening gemaakt dat mogelijk verschillende respondenten uit deze doelgroep twee keer een vragenlijst hebben ontvangen, hetgeen waarschijnlijk een negatief effect heeft op het responspercentage. Van de 283 verstuurde vragenlijsten zijn er uiteindelijk 70 geretourneerd, waarvan 56 reageerden op de door het ROA

2. Het betreft hier de vragenlijst die is voorgelegd aan de arbeidsvoorzieningsinstellingen. 
$-4-$

verstuurde vragenlijsten (respons $20 \%$ ) en 14 op de door het CBA meegestuurde vragenlijsten (respons $5 \%$ ). De totale respons komt daarmee op $25 \%$. Deze respons is als volgt over de doelgroepen verdeeld:

$\begin{array}{lc} & \begin{array}{c}\text { Respons } \\ \text { (aantal) }\end{array} \\ \text { Arbeidsvoorzieningsinstellingen } & 25 \\ \text { Bedrijven } & 5 \\ \text { Onderwijsinstellingen } & 12 \\ \text { Overheidsinstellingen } & 17 \\ \text { Overig } & 11\end{array}$




\section{RESULTATEN GEBRUIKERSONDERZOEK}

In dit hoofdstuk zal achtereenvolgens worden ingegaan op de enquêteresultaten met betrekking tot de in de inleiding geformuleerde centrale onderzoeksvragen:

- Welke organisaties hebben het rapport en de statistische bijlage afgenomen en hoe weet men af van het bestaan ervan?

- Voor welke doeleinden gebruikt men het rapport en de statistische bijlage?

- Welke waardering geeft men het rapport en de statistische bijlage?

- Worden de gegevens in zowel het rapport als de statistische bijlage op de juiste wijze gepresenteerd?

- Bestaan er eventueel speciale gebruikersbehoeften?

- Bestaat er belangstelling voor informatie op diskette?

\section{Afnemende organisaties}

\section{De respons}

In hoofdstuk 2 werd reeds aangegeven dat de gebruikers van het ROA-rapport, voor zover hun adres kon worden achterhaald, kunnen worden opgedeeld in vijf doelgroepen, die qua grootte niet veel verschillen. Tabel 1 laat nogmaals zien hoe deze totale gebruikersgroep is samengesteld en in welke mate de verschillende doelgroepen de vragenlijst hebben ingevuld.

Tabel 1. Samenstelling adressenbestand en respons

\begin{tabular}{lll} 
Doelgroep & $\begin{array}{l}\text { Adressenbestand } \\
\text { (aantal) }\end{array}$ & $\begin{array}{l}\text { Respons } \\
\text { (aantal) }\end{array}$ \\
\hline
\end{tabular}

$\begin{array}{lrr}\text { Arbeidsvoorzieningsinstellingen } & 34 & 25 \\ \text { Bedrijven } & 27 & 5 \\ \text { Onderwijsinstellingen } & 46 & 12 \\ \text { Overheidsinstellingen } & 37 & 17 \\ \text { Overig } & 39 & 11\end{array}$

Vanwege de geringe respons in absolute zin, is het weinig zinvol de enquêteresultaten te presenteren met een verbijzondering naar doelgroep. Dit zal derhalve, op een enkele uitzondering na, ook niet worden gedaan. Wel zal, wanneer er sprake is van duidelijke verschillen tussen de doelgroepen in de beantwoording van de diverse vragen, hier in de begeleidende tekst bij de tabellen op worden ingegaan.

Tabel 2 geeft een beeld van de wijze waarop men kennis heeft genomen van het bestaan van het rapport. Uit de tabel blijkt dat de meeste respondenten het rapport krijgen toegestuurd. Dit geldt voornamelijk voor de doelgroep Arbeidsvoorzieningsinstellingen. De overige groepen hebben meestal via een tijdschrift of krant of via anderen kennis genomen van het ROA-rapport. 
Een onderlinge vergelijking tussen deze groepen laat zien dat er verder vrijwel geen verschil bestaat in de wijze waarop men kennis heeft genomen van het bestaan van het rapport.

Tabel 2. Hoe weet men van het bestaan van het rapport af?

Frequentie

$\begin{array}{lr}\text { Bericht in tijdschrift/krant } & 18\end{array}$

$\begin{array}{ll}\text { Van anderen gehoord } & 18\end{array}$

Het rapport werd door het ROA toegestuurd $\quad 21$

Via verwijzing in andere ROA publikaties $\quad 3$

Via het ROA-jaarverslag/overzicht van publikaties $\quad 5$

\begin{tabular}{ll} 
Overig & 7 \\
\hline
\end{tabular}

De categorie 'overig' is onder te verdelen in de volgende mogelijkheden:

- 'via verwijzing in andere rapporten'

- 'door te bellen met het ROA'

- 'via bibliotheek van de universiteit'

- 'door informatie op te vragen bij het ROA'

- 'via de afdeling P.R. van de R.L.'

- 'via arbeidsvoorziening'

- 'onbekend'

\section{Gebruiksdoelen}

In de enquête is gevraagd naar de doeleinden waarvoor men het rapport en de statistische bijlage gebruikt. Daarbij werden voor iedere doelgroep verschillende antwoordmogelijkheden gespecificeerd. Men had de mogelijkheid meerdere doeleinden aan te geven. Om wille van de overzichtelijkheid van de gepresenteerde resultaten, zal voor iedere doelgroep een 'top 3' van de meest genoemde gebruiksdoelen worden gepresenteerd.

Met uitzondering van de respondenten vanuit de overheidsinstellingen is het 'bekend blijven met de ontwikkeling op de arbeidsmarkt' voor alle doelgroepen het belangrijkste gebruiksdoel. Bij de overheidsinstellingen wordt het gebruik in het kader van de beleidsvoorbereiding het vaakst genoemd. Bij de arbeidsvoorzieningsinstellingen is dit eveneens een belangrijk gebruiksdoel, waarbij ook specifiek gewezen wordt op het gebruik ten behoeve van het scholingsbeleid. Ook het gebruik van de ROA-informatie in het kader van het eigen onderzoek van de gebruikers komt bij verschillende doelgroepen als een belangrijk gebruikdsdoel naar voren.

Vrijwel alle respondenten hebben het rapport en/of de statistische bijlage voor minimaal én van de gespecificeerde doeleinden gebruikt. Van de 70 respondenten heeft slechts 1 respondent aangegeven het rapport niet te hebben gebruikt. De reden hiervoor is dat het rapport 'te weinig specifiek is voor het WO'. Daarbij moet wel worden bedacht dat er waarschijnlijk sprake is van 
een non-respons bias, doordat afnemers die het rapport niet of nauwelijks hebben gebruikt er mogelijk minder belang aan hechten de enquête in te vullen.

Tabel 3. Belangrijke gebruiksdoelen per doelgroep

Frequentie

Arbeidsvoorzieningsinstellingen $(n=25)$

$\begin{array}{ll}\text { Bekend blijven met de ontwikkeling op de arbeidsmarkt } & 18\end{array}$

$\begin{array}{ll}\text { Algemene beleidsvoorbereiding } & 16\end{array}$

$\begin{array}{ll}\text { Scholingsbeleid } & 15\end{array}$

Bedrijuen (n = 5)

Bekend blijven met de ontwikkeling op de arbeidsmarkt 3

Eigen onderzoek 2

Om een beeld te krijgen van de verwachte uitstroom van schoolverlaters 2

Onderwijsinstellingen $(n=12)$

$\begin{array}{ll}\text { Bekend blijven met de ontwikkeling op de arbeidsmarkt } & 10\end{array}$

Algemeen beleid

Overige doeleinden

5

Overheidsinstellingen $(n=17)$

Beleid(svoorbereiding)

Bekend blijven met de ontwikkeling op de arbeidsmarkt

Eigen onderzoek

12

10

Overig $(n=11)$

Bekend blijven met de ontwikkeling op de arbeidsmarkt

Overige doeleinden

7

Eigen onderzoek

4

Voor de aangegeven doeleinden is getracht een waardering van de gebruikswaarde van het rapport en de statistische bijlage te achterhalen. Op een 5-punts schaal $(1=$ slecht, $2=$ matig, $3=$ redelijk, 4 =goed, $5=$ zeer goed) kon men aangeven in welke mate het rapport voor de aangegeven doeleinden te gebruiken is. Door de gemiddelde score voor iedere groep te berekenen, wordt voor de verschillende doelgroepen een indicatie verkregen van de gebruikswaarde van de ROA-informatie (zie tabel 4 ).

Tabel 4 laat zien dat de gemiddelde waarderingsscores bij alle doelgroepen tussen 3 en 4 liggen; dat wil zeggen tussen redelijk en goed. Het 'aantal scores' dat in de tabel wordt weergegeven heeft betrekking op het totaal aantal doeleinden dat een doelgroep heeft aangekruist. Bij een 
significantieniveau van $5 \%$ blijken de waarderingsscores onderling niet significant van elkaar te verschillen ${ }^{3}$.

Tabel 4. Gebruikswaarde rapport en statistische bijlage

$\begin{array}{lll}\text { Doelgroep } & \text { Gemiddelde score } & \text { Aantal scores }\end{array}$

\section{Waardering rapport en statistische bijlage}

Tabel 5. Gemiddelde waarderingsscores rapport en statistische bijlage

$\begin{array}{lrr}\text { Arbeidsbureaus en -voorziening } & 3,72 & 75 \\ \text { Bedrijven } & 3,89 & 9 \\ \text { Onderwijsinstellingen } & 3,39 & 23 \\ \text { Overheidsinstellingen } & 3,43 & 32 \\ \text { Overig } & 3,75 & 16\end{array}$

\begin{tabular}{|c|c|c|c|c|c|}
\hline & $\begin{array}{l}\text { Arbeids- } \\
\text { voorzienings } \\
\text { instellingen }\end{array}$ & Bedrijven & $\begin{array}{l}\text { Onderwijs- } \\
\text { instellingen }\end{array}$ & $\begin{array}{l}\text { Overheids- } \\
\text { instellingen }\end{array}$ & Overig \\
\hline Duidelijke structuur in het rapport? & 4,26 & 4,40 & 4,18 & 4,31 & 4,10 \\
\hline Begrijpelijk taalgebruik in rapport? & 4,39 & 4,40 & 4,18 & 4,37 & 4,00 \\
\hline Algemeen overzicht in hs 1 nuttig? & 4,08 & 4,80 & 4,09 & 4,00 & 3,70 \\
\hline Beroepeninfo voldoende gedetailleerd? & 2,87 & 2,25 & 1,91 & 3,00 & 2,63 \\
\hline Opleidingeninfo voldoende gedetailleerd? & 2,91 & 2,25 & 1,91 & 2,63 & 2,55 \\
\hline 'Technisch onderwijs nader belicht' nuttig? & 3,81 & 3,25 & 3,00 & 4,20 & 3,22 \\
\hline 'Sexe onderwijs en arbeidsmarkt' nuttig? & 3,65 & 3,25 & 3,73 & 3,87 & 3,00 \\
\hline Tabellen rapport overzichtelijk? & 4,22 & 3,80 & 4,18 & 4,13 & 3,90 \\
\hline Tabellen stat. bijlage overzichtelijk? & 4,26 & 3,80 & 4,22 & 4,38 & 3,90 \\
\hline Tabellen stat. bijlage voldoende toegelicht? & 3,52 & 3,75 & 3,11 & 3,56 & 2,55 \\
\hline Verstrekt de stat. bijlage waardevolle info? & 4,13 & 4,00 & 4,00 & 4,00 & 3,80 \\
\hline Is de stat. bijlage toegankelijk? & 3,81 & 4,00 & 4,00 & 3,80 & 3,30 \\
\hline Totaalscore & 3,83 & 3,83 & 3,49 & 3,86 & 3,45 \\
\hline
\end{tabular}

Om de waardering van het rapport te achterhalen, is de geënquêteerden een twaalftal stellingen voorgelegd. Deze stellingen hebben betrekking op de structuur, de overzichtelijkheid en het nut van de verschillende hoofdstukken (zie vragenlijst, vraag 4). Men kreeg de mogelijkheid op een Likertschaal aan te geven in hoeverre men met elk van de beweringen $(1=$ sterk oneens, 2 =oneens, $3=$ neutraal, $4=$ eens, $5=$ sterk eens, $6=$ geen mening/niet van toepassing). Sommige beweringen werden in een negatieve vraagstelling gegoten om de zogenaamde 'yea-

3. Daarbij wordt er vanuit gegaan dat de scores op de 5-punts schaal, interval geschaald zijn. 
sayer, no-sayer bias' te ontwijken ${ }^{4}$. Op deze wijze wordt getracht te vermijden dat de respondent reeds een bepaalde waarde in gedachte heeft voordat hij of zij de bewering leest.

Om inzicht te krijgen in de waardering van de verschillende groepen, worden hieronder de gemiddelde scores op elk van de stellingen met betrekking tot het rapport en de statistisch bijlage weergegeven. Daarbij zijn de scores op de negatief gestelde beweringen vanzelfsprekend omgekeerd $(1=5,2=4$ etc.). Dit betekent dat ook voor de, in eerste instantie negatief gestelde beweringen ( $d, e$, en $j$ ) een hoge score een gunstige waardering impliceert. Daarnaast is antwoordmogelijkheid $6=$ geen mening/n.v.t geëlimineerd.

Op de meeste punten worden het rapport en de statistische bijlage positief gewaardeerd; vrijwel alle scores liggen ruim boven 3. De enige uitzondering hierop vormt de score van de groep 'overig', op bewering j. Deze groep vindt de tabellen in de statistische bijlage onvoldoende toegelicht. Klaarblijkelijk heeft men behoefte aan een uitleg bij de verschillende tabellen. Met name ten aanzien van de structuur, het taalgebruik en de overzichtelijkheid van het rapport en de statistische bijlage is de waardering hoog.

Ook is er een hoge waardering voor het algemene overzicht in hoofdstuk 1 en voor de in de statistische bijlage verstrekte arbeidsmarktinformatie. Opvallend is de relatief lage waardering op de onderdelen $d$ en e. Dit duidt er op dat men de beroepeninformatie en opleidingeninformatie te weinig gedetailleerd vindt. Vooral de lage score van de onderwijsinstellingen op de mate van detail van de opleidingen- en beroepeninformatie springt eruit. Met behulp van een t-toets is nagegaan of de gemiddelde waarderingen van de groepen op een bepaald punt significant van elkaar verschillen (sign. niveau $5 \%$ ). Daarbij worden de volgende significante verschillen tussen de onderscheiden doelgroepen aangetroffen:

* Bedrijven hebben een significant hogere waardering voor het algemeen overzicht in hoofdstuk 1 dan de overige doelgroepen.

* Onderwijsinstellingen hebben een significant lagere waardering voor de mate waarin de beroepeninformatie is gedetailleerd dan de arbeidsvoorzieningsinstellingen en de overheidsinstellingen.

* Onderwijsinstellingen hebben een significant lagere waardering voor de mate waarin de opleidingeninformatie is gedetailleerd dan de arbeidsvoorzieningsinstellingen.

- De 'overige gebruikers' hebben een significant lagere waardering voor de mate waarin de tabellen in de statistische bijlage zijn toegelicht dan de andere gebruikersgroepen.

Om te bepalen welke groep het rapport en de statistische bijlage in zijn totaliteit het best waardeert, is een 'totaalscore' berekend. Daarbij is voor iedere respondent een gemiddelde score over de 12 stellingen vastgesteld. Deze totaalscore is voor de verschillende groepen opnieuw gemiddeld.

4. Zie Alreck, P.L. \& R.B. Settle, The Survey Research Handbook, Richard D. Irwin Inc., Homewood, Illinois, 1985. 
Uit deze totaalscore blijkt dat de algehele waardering voor het rapport en de statistische bijlage doelgroepen dicht bij elkaar liggen. De bedrijven waarderen het rapport het best, gevolgd door achtereenvolgens de Overheidsinstellingen, Arbeidsvoorzieningsinstellingen, Onderwijsinstellingen en Overig. Er is daarbij echter geen sprake van significante verschillen tussen de groepen bij een significantieniveau van $5 \%$.

\section{Aggregatieniveau}

Een belangrijk aandachtspunt in de vragenlijst heeft betrekking op de bij de presentatie van de arbeidsmarktinformatie gehanteerde beroepen- en opleidingenindeling en het aggregatieniveau van de gepresenteerde informatie ${ }^{5}$. Daarbij is getracht te achterhalen welke verdere behoeften er op dit punt bestaan.

Tabel 6. Aggregatieniveau van de gepresenteerde informatie

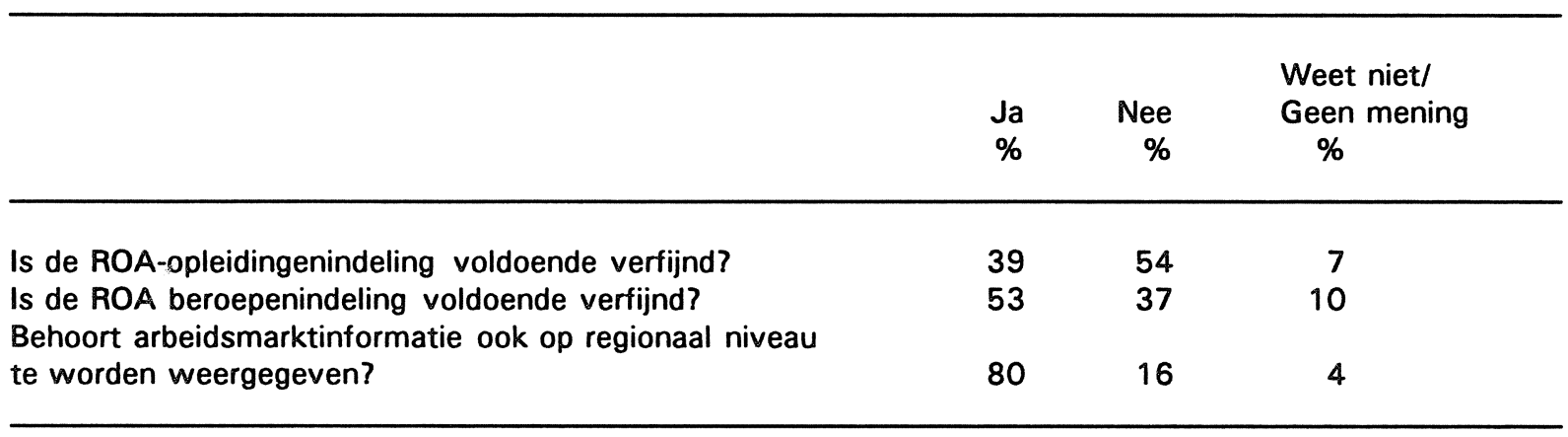

Opvallend is de grote behoefte aan regionale arbeidsmarktinformatie. Tabel 6 geeft een beeld van de mate waarin de gebruikers prijs stellen op gedetailleerde arbeidsmarktinformatie naar opleiding, beroep of regio. Het merendeel van de gebruikers vindt ook dat de gehanteerde opleidingenindeling onvoldoende verfijnd is, terwijl de gebruikte beroepenindeling slechts door een (zij het niet onbelangrijke) minderheid van de gebruikers als onvoldoende verfijnd wordt getypeerd.

Tabel 7. Gewenste niveau voor regionale arbeidsmarktinformatie

3 of 4 landsdelen $\quad 20$

Provincie $\quad 14$

RBA-regio $\quad 61$

Anders $\quad 5$

5. Voor de beantwoording van deze onderzoeksvraag werden vraag $6 a$ en $6 b, 7 a$ en $7 b, 12 a$ en $12 b$ opgesteld (zie vragenlijst). 
Uit tabel 7 blijkt dat het merendeel van de gebruikers die graag zouden zien dat het ROAinformatiesysteem met regionale arbeidsmarktinformatie wordt uitgebreid, het wenselijk achten dat deze informatie betrekking heeft op RBA-regio niveau. Het is niet verbazingwekkend dat vooral de arbeidsvoorzieningsinstellingen veel waarde hechten aan arbeidsmarktinformatie op dit aggregatieniveau. Voor andere gebruikers is een dergelijke vergaande verbijzondering naar regio niet noodzakelijk. Voor hen is het voldoende als de informatie betrekking heeft op 3 of 4 landsdelen of op provincies.

Bij degenen die de opleidingenindeling onvoldoende verfijnd vinden, heeft een verdere opdeling van zowel het wetenschappelijk als het hoger beroepsonderwijs de grootste voorkeur, op slechts geringe afstand gevolgd door HAVO/VWO/MBO (zie tabel 8). Aangenomen mag worden dat in het laatste geval vooral wordt gedacht aan een verdere verfijning van de opleidingen binnen het MBO.

Tabel 8. Opleidingsniveau waarvoor verdere verfijning wenselijk is

Opleidingsniveau $\quad \%$

Basisonderwijs 2

MAVO, LBO/VBO 19

HAVO, VWO, MBO

HBO $\quad 28$

WO $\quad 28$

Degenen die de beroepenindeling voldoende verfijnd vinden, hebben een grote voorkeur voor een verdere opdeling van de economisch-administratieve beroepen. Daarnaast is er een duidelijke belangstelling voor een verdere verbijzondering van de technische ambachts- en industrieberoepen en de verzorgende en dienstverlenende beroepen (zie tabel 9).

Tabel 9. Beroepscategorieën waarvoor verdere verfijning wenselijk is

Verdere verfijining van beroepen: $\%$

$\begin{array}{ll}\text { Pedagogische beroepen } & 6\end{array}$

Culturele beroepen 6

Agrarische beroepen $\quad 7$

Technische ambachts- en industrieberoepen $\quad 17$

Transportberoepen $\quad 7$

Medische en paramedische beroepen $\quad 6$

Economisch-administratieve beroepen $\quad 23$

Sociaal-culturele beroepen 6

Verzorgende en dienstverlenende beroepen $\quad 17$

Openbare orde- en veiligheidsberoepen $\quad 5$ 


\section{Gewenste uitbreidingen arbeidsmarktinformatie}

In de enquête is ook getracht om de eventuele wensen van de gebruikers ten aanzien van de uitbreiding van bepaalde arbeidsmarktinformatie in beeld te brengen. Aandachtspunten daarbij zijn de verschillende typen arbeidsmarktinformatie waarvoor meer uitgebreide informatie wenselijk wordt geacht, de aansluitingsproblematiek tussen schoolverlaters en de verschillende aspecten van de arbeidsmarktproblematiek. Daarbij wordt wederom aandacht besteed aan de verschillende beroepssectoren en opleidingscategorieën. Ten slotte is nagegaan of men naast het ROA-rapport ook andere informatiebronnen gebruikt en of het ROA-rapport op deze bronnen een aanvulling vormt.

Zoals reeds naar voren kwam bij de waardering van de gebruikers voor het aggregatieniveau naar beroep en opleiding, blijkt er vooral behoefte te bestaan aan uitbreiding van arbeidsmarktinformatie naar regio en naar opleiding. Tabel 10 geeft een overzicht van de behoefte aan verdere uitbreiding van arbeidsmarktinformatie.

Tabel 10. Gewenste uitbreidingen arbeidsmarktinformatie

Frequentie $\quad \%$

Geen

$\begin{array}{rr}3 & 1 \\ 26 & 11 \\ 35 & 15 \\ 21 & 9 \\ 41 & 18 \\ 21 & 9 \\ 4 & 2 \\ 31 & 14 \\ 33 & 15 \\ 13 & 6 \\ 0 & 0 \\ 228 & \end{array}$

In totaal is er door de respondenten 228 keer een wenselijk geachte uitbreiding van arbeidsmarktinformatie aangekruist. Dit betekent dat iedere respondent gemiddeld drie voorkeuren heeft aangegeven. Opvallend is dat slechts drie respondenten geen enkele uitbreiding van de gepresenteerde arbeidsmarktinformatie nodig achten. Aansluitend op dit overzicht kan op basis van een afzonderlijk op dit punt gestelde vraag worden gesteld dat $70 \%$ van de respondenten aangeeft een uitbreiding met informatie over de aansluitingsproblematiek tussen schoolverlaters, waardevol te vinden. Dit is waarschijnlijk nogmaals een indicatie voor het belang van opleidingeninformatie voor de respondenten.

Om een wat beter beeld te krijgen van de prioritering ten aanzien van de behoefte aan meer 
uitgebreide arbeidsmarktinformatie, is de respondenten gevraagd een 'top 3' aan te geven met betrekking tot de soort arbeidsmarktinformatie waarvoor de belangstelling het grootst is. Tabel 11 geeft daarvan een overzicht. De weergegeven scores zijn berekend door bij een eerste plaats 3 punten, bij een tweede plaats 2 punten en bij een derde plaats 1 punt toe te kennen.

Tabel 11 . Soort arbeidsmarktinformatie waarvoor belangstelling het grootst is

\begin{tabular}{ll} 
Aandachtspunt & Score \\
\hline $\begin{array}{l}\text { Toekomstige arbeidsmarktsituatie over } 1 \text { à } 2 \text { jaar } \\
\text { Toekomstige arbeidsmarktsituatie over ca. } 5 \text { jaar }\end{array}$ & $(24 * 3+16 * 2+6 * 1)=110$ \\
Actuele werkloosheidssituatie & $(11 * 3+19 * 2+14 * 1)=85$ \\
& $(19 * 3+8 * 2+8 * 1)=81$
\end{tabular}

Tabel 12 geeft een beeld van de voor de gebruiker belangrijkste aspecten van de arbeidsmarktproblematiek. De scores in de tabel bevestigen dat het verder toelichten van opleidingstypen en beroepssectoren een grote voorkeur geniet, die de belangstelling voor de ontgroenings- en vergrijzingsproblematiek en de arbeidsmarktpositie van allochtonen overtreft. Eerder kwam reeds naar voren dat het daarbij vooral gaat om de technische ambachts- en industrieberoepen, verzorgende en dienstverlenende beroepen en economisch-administratieve beroepen (zie tabel 9), terwijl bij de opleidingen de grootste belangstelling uitgaat naar verdergaande verbijzonderingen van de informatie met betrekking tot het hoger beroeps- en het wetenschappelijk onderwijs (zie tabel 10).

Tabel 12. Belangstelling voor bepaalde aspecten van de arbeidsmarktproblematiek

$\begin{array}{ll}\text { Aandachtspunt } & \text { Score }\end{array}$

Het verder toelichten van een opleidingstype

$(22 * 3+21 * 2)=108$

Het verder toelichten van een beroepssector

$(25 * 3+11 * 2+7 * 1)=104$

Arbeidsmarktpositie van vrouwen

$(3 * 3+13 * 2+9 * 1)=44$

Het huidige rapport ('De arbeidsmarkt naar opleiding en beroep tot 1994') bevat twee thematische hoofdstukken die achtereenvolgens dieper ingaan op de samenhang tussen geslacht, onderwijs en arbeidsmarkt en het technisch onderwijs. In de enquête is gevraagd naar de voorkeuren met betrekking tot de invulling van een thematisch hoofdstuk met een bepaalde beroepssector en opleidingscategorie. Daarbij is wederom gevraagd een 'top 3' op te stellen.

Uit tabel 13 blijkt dat er grote voorkeur bestaat voor meer informatie over economischadministratieve beroepen en technische ambachts- en industrieberoepen, op enige afstand gevolgd door de verzorgende en dienstverlenende beroepen. Dit beeld bevestigt de eerder aangegeven voorkeuren voor verdere verfijningen van een bepaalde beroepsselectie. 
Tabel 13. Voorkeuren voor extra hoofdstuk over bepaalde beroepssector

Beroepssector Score

Economisch-administratieve beroepen

$(21 * 3+12 * 2+4 * 1)=91$

Technische ambachts- en industrieberoepen

$(21 * 3+8 * 2+4 * 1)=83$

Verzorgende en dienstverlenende beroepen

$(5 * 3+12 * 2+11 * 1)=50$

Tabel 14. Voorkeuren voor extra hoofdstuk over bepaalde opleidingscategorieën

Opleidingscategorieën

Score

Hoger onderwijs (HBO, WO)

LBO/VBO

Voortijdige schoolverlaters ('drop outs')

$(27 * 3+4 * 2+3 * 1)=92$

$(11 * 3+13 * 2+8 * 1)=67$

$(13 * 3+8 * 2+9 * 1)=64$

Tabel 14 geeft een beeld van de voorkeuren voor de invulling van een theoretisch hoofdstuk met betrekking tot een bepaalde opleidingscategorie. Hier blijkt opnieuw de grote belangstelling van arbeidsmarktinformatie met betrekking tot het hoger beroeps- en wetenschappelijk onderwijs. Daarnaast is er belangstelling voor een toespitsing op het LBO/VBO en de voortijdige schoolverlaters.

Tenslotte is gevraagd of men naast de ROA-informatie ook gebruik maakt van andere informatiebronnen. Aansluitend daarop is gevraagd of het ROA rapport wat dat betreft 'extra' informatie geeft; dat wil zeggen informatie die niet in de andere bronnen is terug te vinden. Maar liefst $97 \%$ van de respondenten gebruikt naast het ROA rapport nog andere informatiebronnen (zie tabel 15). Van deze bronnen worden het CBS, de werkloosheids- en vacaturecijfers van de arbeidsvoorzieningsorganisatie en de schoolverlatersbrief het meest genoemd:

Tabel 15. Andere gebruikte informatiebronnen

\begin{tabular}{lrr}
\hline & Frequentie & $\%$ \\
\hline & & \\
CBS gegevens & 56 & 26 \\
ETIL gegevens & 8 & 5 \\
Werkloosheids- en vacaturecijfers Arbeidsvoorziening & 50 & 23 \\
RUBS-Schoolverlatersenquête & 25 & 10 \\
HBO-monitor & 21 & 6 \\
Schoolverlatersbrief & 46 & 21 \\
Interne informatiebronnen & 20 & 7 \\
Overig & 23 & 2 \\
Totaal & 249 & 100 \\
\end{tabular}


Om een zo volledig mogelijk beeld te krijgen van de informatiebronnen die naast het ROA rapport worden gebruikt, kan een opsomming worden gegeven van de gebruikte interne informatiebronnen en de overige informatiebronnen.

Als interne informatiebronnen worden onder andere genoemd:

- 'eigen onderzoek/rapporten'

- 'Integrale leerlingstellingen'

- 'knipselkranten'

- 'diverse $O \& W$ registraties'

Als overige informatiebronnen worden onder andere genoemd:

- 'rapporten in opdracht van ministerie'

- 'beroepsvereniging'

- 'eigen informatie uit de regio'

- 'universiteit, KNCV'

- 'rapporten RUG, CAB'

- 'RBA-gegevens'

- 'Kwartaalbericht SZW'

- 'Sociale nota SZW'

- 'eigen onderzoek'

- 'eigen vakliteratuur, informatie van landelijke organen'

- 'andere onderzoeken'

De meerwaarde die het ROA-rapport voor de gebruikers heeft ten opzichte van de andere informatiebronnen heeft vooral betrekking op de verwachte arbeidsmarktontwikkelingen. Maar liefst $39 \%$ van de respondenten vindt dat het ROA op dit gebied 'extra' informatie verstrekt (zie tabel 16). Vanuit een andere invalshoek vormen vooral de beroepen, en in iets mindere mate de opleidingen, de gebieden waarop het ROA goed scoort wat betreft het verstrekken van 'extra' informatie. Gunstig is het feit dat alle respondenten aangeven dat het ROA-rapport over én of meerdere gebieden 'extra' informatie verstrekt.

Tabel 16. ROA-informatie die niet in andere informatiebronnen is terug te vinden

$\%$

$\begin{array}{lr}\text { Over opleidingen } & 18\end{array}$

$\begin{array}{ll}\text { Over beroepen } & 23\end{array}$

$\begin{array}{ll}\text { Over de actuele arbeidsmarktinformatie } & 11\end{array}$

Over de verwachte arbeidsmarktontwikkeling $\quad 39$

$\begin{array}{ll}\text { Over geen enkel gebied } & 1\end{array}$

$\begin{array}{ll}\text { Anders } & 8\end{array}$

$\begin{array}{ll}\text { Totaal } & 100\end{array}$ 
Een belangrijk probleempunt bij het combineren van de ROA-informatie met de andere informatiebronnen is het ontbreken van de mogelijkheid om de gehanteerde indelingen te kunnen vergelijken. Maar liefst $84 \%$ van de respondenten ondervindt op dit punt problemen. Aangenomen mag worden dat met name de koppelbaarheid tussen de door het ROA gehanteerde CBSclassificaties en de beroepen- en opleidingenindelingen van de Arbeidsvoorzieningsorganisatie voor veel gebruikers een belangrijk knelpunt is. Daarentegen is de informatie uit het ROArapport koppelbaar met de informatie uit de RUBS-schoolverlatersenquête en de HBO-monitor. Het is echter goed denkbaar dat een dergelijke koppeling voor veel gebruikers van de informatie te veel problemen oplevert en/of te tijdrovend is.

\section{Belangstelling voor informatie op diskette}

Ruim $60 \%$ van de respondenten geeft aan belangstelling te hebben voor een diskette met de ROA-arbeidsmarktinformatie. Hierbij heeft de actuele arbeidsmarktinformatie met betrekking tot opleidingen een lichte voorkeur. De verschillen in belangstelling met de andere typen informatie zijn echter klein (zie tabel 17).

Tabel 17. Gewenste informatie op diskette

\begin{tabular}{lcc}
\hline & Frequentie & $\%$ \\
\hline & & \\
De gehele statistische bijlage & 21 & 15 \\
Actuele arbeidsmarktinformatie over beroepen & 22 & 16 \\
Actuele arbeidsmarktinformatie over opleidingen & 26 & 18 \\
Arbeidsmarktindicatoren voor beroepen & 14 & 10 \\
Arbeidsmarktindicatoren voor opleidingen & 19 & 13 \\
Prognoses voor beroepen & 17 & 12 \\
Prognoses voor opleidingen & 22 & 16 \\
Overig & 0 & 0 \\
Totaal & 141 & 100 \\
\hline
\end{tabular}

Tabel 18. Gewenste presentatie van informatie op diskette

\begin{tabular}{lrr}
\hline & Frequentie & $\%$ \\
\hline Tabellen & 3 & 5 \\
Tabellen + korte toelichting & 16 & 26 \\
Tabellen + tekst & 12 & 20 \\
Zelf te manipuleren tabellen (spreadsheets) & 30 & 0 \\
Anders & 0 & 100 \\
Totaal & 61 & 19 \\
\hline
\end{tabular}


Tabel 18 geeft aan dat ten aanzien van de wijze waarop de arbeidsmarktinformatie op diskette aangeboden zou moeten worden, de voorkeur uitgaat naar spreadsheets. Daarnaast is er bij een groep gebruikers vooral belangstelling voor informatie in de vorm van kant en klare tabellen aangevuld met tekst, c.q. een korte toelichting. Van de ruim $60 \%$ van de respondenten die zegt belangstelling te hebben voor een diskette, vindt ongeveer $60 \%$ dat de diskette menu-gestuurd moet zijn.

Daarnaast werd gevraagd voor welke doeleinden men de diskette wenst te gebruiken. Om wille van de overzichtelijkheid, wordt in tabel 19 per doelgroep het meest genoemde doel weergegeven:

Tabel 19. Belangrijkste gebruiksdoel op diskette, per doelgroep

Organisatie Gebruiksdoel

Arbeidsvoorzieningsinstellingen

Bedrijven

Onderwijsinstellingen

Overheidsinstellingen

Overig

\author{
Algemene beleidsvoorbereiding \\ Eigen onderzoek \\ Bekend blijven met de ontwikkeling op de \\ arbeidsmarkt \\ Algemene beleid(svoorbereiding) \\ Bekend blijven met de ontwikkeling op de \\ arbeidsmarkt
}

Tenslotte is, om een beter beeld te krijgen van de respondenten, gevraagd welke functie men bekleedt. Uit tabel 20 blijkt dat de gebruikersgroep voor een belangrijk deel betrekking heeft op beleidsmedewerkers en onderzoekers en slechts in zeer beperkte mate degenen bereikt die werkzaam zijn in een functie waarin de studie- en beroepskeuzevoorlichting centraal staat. Dit laatste stemt overigens overeen met de beoogde afbakening tussen de doelgroepen van het ROA-rapport en de doelgroepen van de informatieprodukten van het LDC.

Tabel 20. Functie uitgeoefend door respondenten

Frequentie

$\begin{array}{lr}\text { Decaan } & 1 \\ \text { Beroepskeuze adviseur } & 2 \\ \text { Arbeidsconsulent } & 3 \\ \text { Personeelsfunctionaris } & 2 \\ \text { Beleidsmedewerker } & 22 \\ \text { Onderzoeker } & 20 \\ \text { Directeur } & 6 \\ \text { Overig } & 12 \\ \text { Totaal } & 68\end{array}$




\section{BESLUIT}

Tot slot, zullen de belangrijkste bevindingen van het onderzoek in deze pararaaf op een rijtje worden gezet:

\section{Doelgroep}

In het gebruikersonderzoek zijn een vijftal doelgroepen onderscheiden: arbeidsvoorzieningsinstellingen, bedrijven, onderwijsinstellingen, overheidsinstellingen en overig. Het merendeel van de gebruikers heeft via anderen of door middel van een bericht in een tijdschrift of krant kennis genomen van het bestaan van het ROA-rapport.

\section{Doeleinden}

Het rapport wordt vooral gebruikt om 'bekend te blijven met de ontwikkeling op de arbeidsmarkt'. De respondenten geven aan dat het rapport redelijk tot goed te gebruiken is voor hun doeleinden. Daarbij treden er geen significante verschillen op tussen de doelgroepen.

\section{Waardering}

De gebruikers hebben een positieve waardering voor de structuur, het taalgebruik, de overzichtelijkheid en het nut van het rapport en de statistische bijlage. Over het algemeen wordt het rapport goed gewaardeerd, waarbij er geen significante verschillen tussen de doelgroepen optreden. De overheidsinstellingen hebben de hoogste waardering voor het rapport, gevolgd door achtereenvolgens de arbeidsvoorzieningsinstellingen, bedrijven, onderwijsinstellingen en de overige gebruikers. Opvallend is de lage waardering voor de mate van detail van de beroepenen opleidingeninformatie, hetgeen aangeeft dat men de beroepen- en opleidingeninformatie onvoldoende gedetailleerd vindt.

\section{Gebruikersbehoefte}

1. Liefst $80 \%$ van de respondenten zou graag zien dat ook op regionaal niveau arbeidsmarktinformatie wordt gepresenteerd. Het merendeel heeft daarbij een voorkeur voor het niveau van de RBA-regio, gevolgd door een groep die de voorkeur geeft aan een indeling in 3 of 4 landsdelen.

2. Meer dan de helft van de respondenten vindt de opleidingenindeling onvoldoende verfijnd. Opvallend is de sterke voorkeur voor een verdere verfijning van het Hoger Beroeps- en Wetenschappelijk Onderwijs.

3. lets minder dan $40 \%$ van de respondenten vindt de beroepenindeling onvoldoende verfijnd. Opvallend is de sterke voorkeur voor een verdere verfijning van de economisch-administratieve beroepen, de dienstverlenende en verzorgende beroepen en de technische ambachts- en 
$-19-$

industrieberoepen. Overigens kan dit ook worden geïnterpreteerd als een behoefte ten aanzien van de opleidingscategorieën (waar niet naar vakrichtingen werd gevraagd); dat wil zeggen: als een behoefte aan een verdere verfijning van bijvoorbeeld het economischadministratief en technisch onderwijs.

4. Met betrekking tot de gewenste uitbreiding van arbeidsmarktinformatie, kan worden geconcludeerd dat de gebruikers de grootste behoefte hebben aan meer verfijnde informatie naar regio, gevolgd door informatie naar opleiding en arbeidsmarktprognoses op middellange termijn.

5. De gebruikers hebben in het algemeen de grootste belangstelling voor 'de toekomstige arbeidsmarktsituatie over 1 à 2 jaar'. Dit geldt met name voor de gebruikers vanuit de Arbeidsvoorzieningsinstellingen. Wanneer men kijkt naar de verschillende aspecten die bij de arbeidsmarktproblematiek een rol spelen, dan blijkt dat de respondenten veruit de grootste belangstelling hebben voor: 'het verder toelichten van een opleidingstype' en 'het verder toelichten van een beroepssector'. Pas daarna volgt de belangstelling van informatie met betrekking tot de arbeidsmarktpositie van normen, allochtonen en de informatie met betrekking tot de vergrijzings- en ontgroeningsproblematiek.

6. Met betrekking tot de beroepssectoren, bestaat er vooral behoefte aan meer informatie over technische ambachts- en industrieberoepen en economisch-administratieve beroepen. Binnen de opleidingscategorieën heeft men vooral behoefte aan extra informatie over het Hoger Onderwijs (HBO, WO).

7. In vergelijking met andere informatiebronnen, ligt de sterkte van het ROA-rapport bij de informatie over de verwachte arbeidsmarktontwikkeling. Vooral op dit gebied verstrekt het ROA-rapport informatie die niet in deze andere bronnen is terug te vinden. Andere gebieden waarop het ROA goed scoort, dat wil zeggen 'extra informatie verstrekt, zijn (meer in het algemeen) informatie over opleidingen en informatie over beroepen.

8. Ruim $60 \%$ van de respondenten zegt belangstelling te hebben voor ROA-informatie op diskette. Daarbij gaat de voorkeur uit naar actuele arbeidsmarktinformatie over beroepen en opleidingen. De informatie moet bij voorkeur, in de vorm van zogenaamde spreadsheets ter beschikking worden gesteld, hoewel een andere gebruikersgroep bij voorkeur de informatie in tabelvorm (met toelichting) op diskette zou willen hebben. 


\section{BIJLAGE 1. VRAGENLIJST}

Bijlage: de vragenlijst bij het onderzoek naar de gebruikswaarde van het ROA-rapport: 'De arbeidsmarkt naar opleiding en beroep tot 1994'. Bijgevoegd is de versie Arbeidsvoorzieningsinstellingen.

Vragenlijst bij het gebruikersonderzoek betreffende het ROA-rapport:

De Arbeidsmarkt naar Opleiding en Beroep tot $1994^{\circ}$ 
op welke wijze hest U kennis genomen van het bestaan van het ROA rapport T Do Arbeidsmarkt naar Opleding en Beroep tot $1994^{\text {' }}$ on do bijbeho rendo statistische bilage?

2a Voor welke doeleinden heeft U het rapport en de statistischo biliago gabruikt?

(Er zin meerdero antwoorden nogelik)

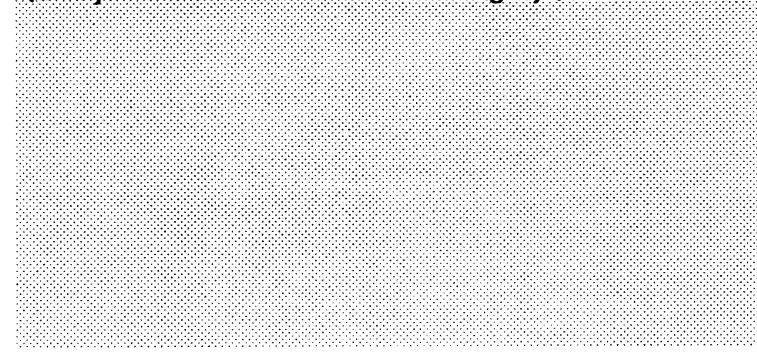

Wilt U bif do aangekruiste doeleinden a angeven hoe goed het rapport on do statistischo bilago voor dezo doeleinden to gebruiken zin.

$\mathrm{U}$ kunt dit doen door het ciffer van UW keuze te omcirkelen.

Ga daama verder met vraag 4.

\author{
Bericht in tijdschrift / krant \\ Van anderen gehoord \\ Het rapport werd door ROA toegestuurd \\ Via verwijzing in andere ROA publikaties \\ Via het ROA jaarverslag / overzicht publikaties \\ Overig, nl.
}

Het rapport is door ons niet gebruikt

lindien $U$ deze antwoordmogelijkheid heeft aangekruist, ga dan verder met vraag 3)

Voor eigen onderzoek

Voor studie-en beroepskeuze voorlichting

Voor andersoortige voorlichting

Voor algemene beleidsvoorbereiding

Voor het scholingsbeleid

Voor arbeidsbemiddeling

$\square$ Voor het bekend blijven met de ontwikkeling op de arbeidsmarkt

Overig, $\mathrm{nl}$.
Voor eigen onderzoek

Voor studie-en beroepskeuze voorlichting

Voor andersoortige voorlichting

Voor algemene beleidsvoorbereiding

Voor het scholingsbeleid

Voor arbeidsbemiddeling

Voor het bekend blijven met de ontwikkeling op de arbeidsmarkt

Overig, nl.

$$
\begin{aligned}
& 1 \text { = slecht } \\
& 2 \text { natig } \\
& 3 \text { - redeljk } \\
& 4 \text { boed } \\
& 5 \text { - zoor poed }
\end{aligned}
$$
1

slecht

zeer

goed

$\begin{array}{lllll}1 & 2 & 3 & 4 & 5 \\ 1 & 2 & 3 & 4 & 5 \\ 1 & 2 & 3 & 4 & 5 \\ 1 & 2 & 3 & 4 & 5 \\ 1 & 2 & 3 & 4 & 5 \\ 1 & 2 & 3 & 4 & 5 \\ 1 & 2 & 3 & 4 & 5 \\ 1 & 2 & 3 & 4 & 5\end{array}$

Ga nu verder met vraag 4. 
Waarom heeft $U$ het rapport en de statistische bijlage niet gebruikt?

(Er zijn meerdere antwoorden mogelijk)
Het rapport heeft een onduidelijke structuur De inhoud van het rapport is te wetenschappelijk Het rapport bevat te vage en abstracte gegevens Het rapport bevat teveel cijfers

De gegevens zijn reeds bekend uit andere bronnen We beschikten te laat over het rapport

Overig, nl.

\section{Toelichting bij vraag 4:}

In het ROA-rapport wordt in hoofdstuk 1 een beschrijving gegeven van de algemene ontwikkeling op de arbeidsmarkt. De hoofdstukken 2 en 3 gaan dieper in op de arbeidsmarktpositie van de diverse opleidingen en beroepen. De hoofdstukken 4 en 5 zijn thematische hoofdstuk$k e n$ die dieper ingaan op het technisch onderwijs en de arbeidmarktpositie van vrouwen. In de statistische bijlage wordt de bijbehorende kwantitatieve informatie in 27 tabellen gepresenteerd.

In vraag 4 vragen wij naar een algemeen oordeel over de bruikbaarheid en de structuur van het rapport en de statistische bijlage. Ook al heeft $U$ slechts delen van het rapport gebruikt, of vindt $U$ het rapport niet of slecht bruikbaar, dan toch zouden wij graag Uw oordeel over de in vraag 4 geformuleerde beweringen vernemen.

4 Hieronder staan een aental beweringen opgesomd. Wilt $U$ aangeven in hoeverre $U$ met elk van de be. weringen instemt? $\mathrm{O}$ kunt dit doen door het cijter dat overeenkomt met UW keuze te omcirkelen.

a) Het rapport heeft een duidelijke structuur

b) Het taalgebruik in het rapport is begrijpelijk

c) Het is voor ons nuttig dat in hoofdstuk 1 een algemeen overzicht van de arbeidsmarkt wordt gegeven

d) De arbeidsmarktinformatie naar beroepen is te weinig gedetailleerd

e) De arbeidsmarktinformatie naar opleidingstypen is te weinig gedetailleerd

f) Het hoofdstuk: "Het technisch onderwijs nader belicht" is voor ons nuttig

g) Het hoofdstuk: "Sexe, onderwijs en arbeidsmarkt", is voor ons nuttig

h) De tabellen in het rapport zijn overzichtelijk

i) De tabellen in de statistische bijlage zijn overzichtelijk

j) De tabellen in de statistische bijlage worden onvoldoende toegelicht

k) De statistische bijlage verstrekte waardevolle informatie

1) In de statistische bijlage kun je snel vinden wat je zoekt

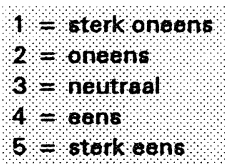

sterk

sterk geen oneens eens mening/ niet van toepassing

$\begin{array}{llllll}1 & 2 & 3 & 4 & 5 & 6 \\ 1 & 2 & 3 & 4 & 5 & 6 \\ 1 & 2 & 3 & 4 & 5 & 6\end{array}$

1

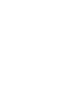

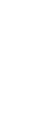

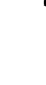

1

1

1

1

1 
Welko arbeidsmarktinformatio moet voor UW doel ainden, worden uitgebreid?

(Er zijn meerdero ontwoorden mogelijk)

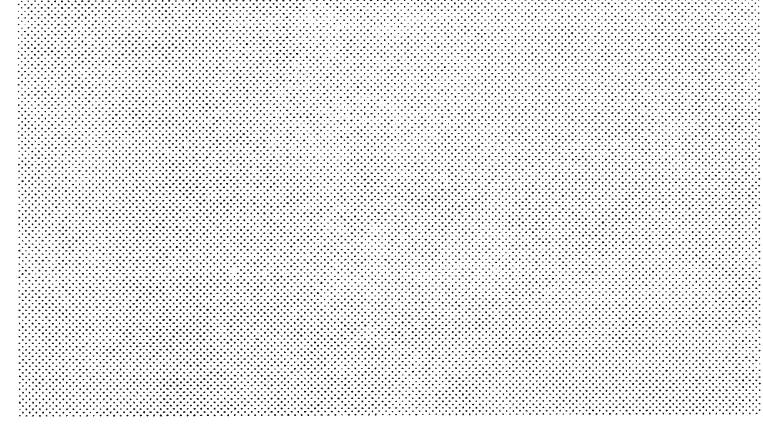

Het ROA zou in zin rapport dieper kunnen ingaan op do aansluithosproblematiek tussen schoolverla ters en de arbeidsmarkt. Is voor Uw doeleinden. Uitbreiding met deze informatie waardevol?

6a Do ROA opleidingenindeling onderscheidt $47 \mathrm{cate}$ gorieen. verdeeld naar 6 opleidingsniveauls. $\mathrm{s}$ d deze indeling voor Uw doeleinden voldoende verfind?

6b Welke opleidingen moeten verder worden opge deeld?

(Er zijn meerdere antwoorden mogelijk)

7a Do ROA berooponindeling onderscheidt 93 beroeps. klassen. Is deze indeling voor UW doeleinden vol doende vertind?

7b Welke beroepen moeten verder worden opgedeeld? (er $\mathrm{ziln}$ meerdere an twoorden mogelijk)
Geen uitbreiding nodig

Arbeidsmarktinformatie naar beroep

Arbeidsmarktinformatie naar opleiding

Arbeidsmarktinformatie naar bedrijfstak

Arbeidsmarktinformatie naar regio

Actuele arbeidsmarktinformatie

Arbeidsmarktindicatoren (bijv. de spreidingsindicator)

Arbeidsmarktprognoses op korte termijn lover 1 of 2 jaar)

Arbeidsmarktprognoses op middellange termijn lover 5 jaar)

Arbeidsmarktprognoses op lange termijn lover 10 jaar)

Anders, $\mathrm{nl}$.

\section{$\mathrm{Ja}$}

Nee

Weet niet / geen mening

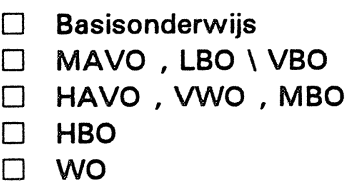

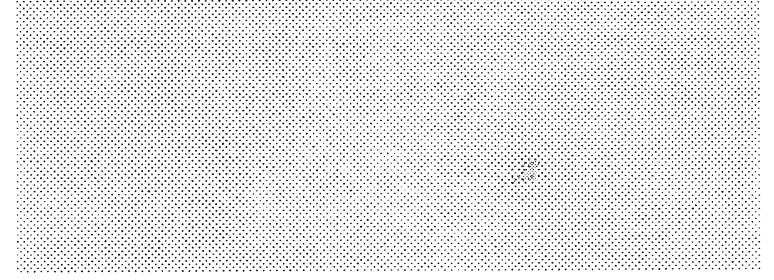

Pedagogische beroepen

Culturele beroepen

Agrarische beroepen

Technische ambachts-en industrieberoepen

$\square$ Transportberoepen

$\square$ Medische en paramedische beroepen

$\square$ Economisch-administratieve beroepen

$\square$ Sociaal-culturele beroepen

$\square$ Verzorgende en dienstverlenende beroepen

$\square$ Openbare orde-en veiligheidsberoepen

erder met vraag 8

$\rightarrow$ Ga verder met vraag 7b 
Welko orbeidsmarktinformatio heeft $/$ i het alge meen Uw grootsto belangstelling?

U kunt by deze vraag een top 3 t eangevent dat wit zeggen nummer / heeft UW grootste belang stelling. nummer 2 heeft vervolgens $U \mathrm{~W}$ belangstel. ling en tor stot kunt $U$ nog een derde plaats aange ven.

De arbeidsmarktproblematiek heeft verschillende aspecten. Welk ospect heeft UW grootste belangstelling?

O kunt bif deze vraag wederom een top 3 ' aangeven Nummer 1 heeft UW grootste belangstelling. Vervolgens heeft nummer 2 Uw grootste belang. stelling, wasma $\mathrm{U}$ nog een nummer 3 kunt aangeven

Stel, U mag bepalen aan welke beroepssector in het rapport een extra hoofdstuk wordt besteed. Welko zou dit dan zilin?

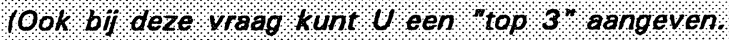
Nummer 1 heeft Uw grootste belangstelling, ge volgd ooor de nummers 2 en 3 )

11 Stel, 1 mag bepalen welke opleidingscategorie nader wordt belicht. Welko 200 dit dan ziln?

10 runt wederom een top 3 a angeven. Nummer 1 heeft 0 w grootste belangstelling, gevolgd door de nummers 2 en 3 )

$12 \mathrm{a}$ Vindt $\mathrm{U}$ dat de erbeidsmarktinformatie ook op regionaal niveau moet worden weergegeven?

$12 \mathrm{~b}$ op well niveau moet deze regionale informatio dan worden weergogeven?

(Er is slechts, entwoord mogelik)

Toelichting:

Hovd bo d de beantwoording van vraag 126 rekening met het volgende. naarmate een oroter a antal re glo s wordt onderscheiden, 2 al od arbeidsmarktin formatie voor beroepen en opleidingen minder gedetalleerd kunnen zin.
Informatie over:

... Actuele werkloosheidssituatie

... Toekomstige arbeidsmarktsituatie over 1 à 2 jaar

... Toekomstige arbeidsmarktsituatie over ca. 5 jaar

... Toekomstige arbeidsmarktsituatie over ca. 10 jaar

... Uitwijkmogelijkheden op de arbeidsmarkt

... Relatie tussen opleidings-en functieniveau (over- en onderbenutting)

... Anders, $\mathrm{nl}$.

... Ontgroening

... Vergrijzing

... Arbeidsmarktpositie van allochtonen

... Arbeidsmarktpositie van vrouwen

... Het verder toelichten van een beroepssector

... Het verder toelichten van een opleidingstype

Geen

Pedagogische beroepen

... Culturele beroepen

... Agrarische beroepen

... Technische ambachts-en industrieberoepen

... Transportberoepen

... Medische en paramedische beroepen

... Economisch-administratieve beroepen

... Sociaal-culturele beroepen

... Verzorgende en dienstverlenende beroepen

... Openbare orde-en veiligheidsberoepen

... Anders, $\mathrm{nl}$.

Geen

... Voortijdige schoolverlaters ("drop outs")

... LBO / VBO

... MAVO , HAVO , VWO

... Leerlingwezen

... Hoger onderwijs (HBO, WO)
3 of 4 landsdelen (Noord, Zuid, Oost, West) Provincie

RBA-regio

Anders, nl. 
13 a Gebruikt 4 haast het ROA rapport IDe Arbeids markt naer Opleiding en Beroep tot 1994$),$ nog andere bronnen van arbeidsmarktinformatie?

$13 \mathrm{~b}$ Welke endere informatiebronnen zijn dit? (Er zilh meerdere antwoorden mogelijk)

$13 \mathrm{c}$ over welke gebieden geeft het ROA rapport IDe Arbeidsmarkt naar Opleiding en Beroep) informatio die niet in de bovengenoemde andere informatiebronnen is terug te vinden?

(Er zijn meerdere antwoorden mogelijk)

$13 \mathrm{~d}$ Hanteert het $\mathrm{ROA}$ rapport 1 De Arbeidsmarkt naar Opleiding en Berbep tot 1994 ) dezelfde classificaties als de bil 136 , door $U$, genoemde andere infor matiebronnen, 20 dat de verschillende informatie bronnen vergelijkbaar zijn?

14 a Heeft 0 belangstelling voor een disketto met de ROA-arboidsmarktgegevens?

14b Welke intormatie moot dan op diskette worden weergegeven?

(Er zijn meerdero antwoorden mogellik)

14c In welko vorm moet de informatio op diskette ter beschikking worden gesteld?

(Er zin meerdere antwoorden mogelijk)

14d Voor welke doeleinden wilt U de diskette gebrul ken?

(Er zijh meerdere antwoorden mogellik)

$14 \mathrm{e}$ Dient de informatie op diskette menu gestuurd te ziin?

\section{$\mathrm{Ja} \quad \rightarrow$ Ga verder met vraag 13b \\ Nee $\rightarrow$ Ga verder met vraag 14a}

Over opleidingen

Over beroepen

Over de actuele arbeidsmarktsituatie

Over de verwachte arbeidsmarktontwikkeling

Over geen enkel gebied

Anders, $\mathrm{nl}$.

Ja

Nee

Weet niet / geen mening

\section{Ja $\quad \rightarrow$ Ga verder met vraag 14b \\ Nee $\quad \rightarrow$ Ga verder met vraag 15}

De gehele statistische bijlage

Actuele arbeidsmarktinformatie over beroepen

Actuele arbeidsmarktinformatie over opleidingen

Arbeidsmarktindicatoren voor beroepen

Arbeidsmarktindicatoren voor opleidingen

Prognoses voor beroepen

Prognoses voor opleidingen

Overig, nl.

Tabellen

Tabellen + korte toelichting

Tabellen + tekst

Zelf te manipuleren tabellen (spreadsheets), geschikt voor eigen onderzoek

Anders, $\mathrm{nl}$.

Voor eigen onderzoek

Voor studie-en beroepskeuze voorlichting

Voor andersoortige voorlichting

Voor algemene beleidsvoorbereiding

Voor het scholingsbeleid

Voor arbeidsbemiddeling

Voor het bekend blijven met de ontwikkeling op de arbeidsmarkt

Overig, $\mathrm{nl}$

$\mathrm{Ja}$

Nee

Maakt niet uit / geen mening 
Tot slot willen wij $U$ vragen bij welke organisatie $U$ werkzaam bent en welke functie $U$ bekleedt.

1) Bij welk soort organisatie bent $U$ werkzaam?
$\square$ School
$\square$ Arbeidsbureau
$\square$ Lokale / regionale overheid
$\square$ Rijksoverheid
$\square$ Commercieel bedrijf
$\square$ Regionaal Diensten Centrum
$\square$ Overig, nl.

2) Welke functie bekleedt U?
$\square$ Decaan
$\square$ Beroepskeuze adviseur
$\square$ Arbeidsconsulent
$\square$ Personeelsfunctionaris
$\square$ Medewerker scholingsbeleid
$\square$ Beleidsmedewerker
$\square$ Onderzoeker
$\square$ Directeur
$\square$ Overig, nl. 


\title{
BIJLAGE 2. SPECIFIEKE ANTWOORDMOGELIJKHEDEN VOOR ANDERE DOEL- GROEPEN.
}

\author{
Antwoordmogelijkheden bij de vragen 2a en $14 d$ voor de doelgroepen: bedrijven, onderwijsinstellingen, \\ overheidsinstellingen en "overig". \\ $2 a \quad$ Voor welke doeleinden heeft $U$ het rapport en de statistische bijlage gebruikt? \\ 14d Voor welke doeleinden wilt $U$ de diskette gebruiken?
}

\section{Bedrijven:}

$\square$ Voor eigen onderzoek

$\square$ Voor het personeelsbeleid

$\square$ Om een beeld te krijgen van de verwachte uitstroom van schoolverlaters

$\square$ Voor het bekend blijven met de ontwikkeling op de arbeidsmarkt

$\square$ Overig, nl.

\author{
Onderwijsinstellingen: \\ $\square$ Voor studie- en beroepskeuze voorlichting \\ $\square$ Voor het P.R. beleid \\ [ Voor het algemene beleid \\ $\square$ Voor het bekend blijven met de ontwikkeling op de arbeidsmarkt \\ $\square$ Voor gebruik binnen les \\ $\square$ Overig, nl.
}

\author{
Overheidsinstellingen: \\ $\square$ Voor eigen onderzoek \\ ¿ Voor beleid(svoorbereiding) \\ $\square$ Voor studie- en beroepskeuze voorlichting \\ $\square$ Voor andersoortige voorlichting \\ $\square$ Voor het bekend blijven met de ontwikkeling op de arbeidsmarkt \\ $\square$ Overig, nl.
}

"Overig":

Voor eigen onderzoek

Om een beeld te krijgen van de verwachte uitstroom van schoolverlaters

$\square$ Voor het bekend blijven met de ontwikkeling op de arbeidsmarkt

$\square$ Overig, $\mathrm{nl}$. 